\title{
3 \\ Venal office and the royal breakthrough
}

The magistrates of the parlements, like office-holders throughout the royal administration, held their offices as property in almost the same sense that one owned real estate or moveables - almost, but not quite. More precisely, an officeholder owned the finance or financial assets in the office; he exercised its title, function and authority as a temporary delegation from the king, a usufruct. The king could reclaim the office by refunding the finance to the office-holder; but only rarely did he have the money or the inclination to do so. Most officeholders held on to their posts for life. ${ }^{1}$

In edicts dealing with parlementary venality, kings often stipulated that office was the most important element in the wealth of the judges and accepted some responsibility for preserving its value. The magistrates happily accepted these assurances and looked to the king when financially pressed. They maintained that wealth imparted status, evoked respect and went hand in hand with the administration of justice, while poverty would render them incapable of serving. Even Richelieu, who considered abolishing venality, consoled himself with this rationalization. ${ }^{2}$

Modern scholars have adopted a corollary of this thesis, suggesting that the office-holders became so numerous and so heavily invested in venality that they constituted a check upon royal power. Lavisse and Mousnier, although representing different scholarly traditions, shared this opinion, and contemporary revisionists have founded their interpretation upon it. Moote believed that the Fronde taught the monarchy such a political lesson that it resolved never again to risk its authority by endangering interests in venal office. Parker and Mettam, expanding upon Moote and inspired by Beik, thought that the kings reached a social compromise with office-holders, intentionally making them into partners of absolute government by respecting their venal interests and bolstering their economic and social position. Revisionism firmly insists that Louis XIV treated the venal interests of the parlementary judges with particular delicacy. It argues, in the manner of Lavisse and Mousnier, that on the issue of venality the upper magistracy still limited the authority of the king. On this reading, 
Louis XIV's victory on the registration of the laws would be incomplete, if not suspect. $^{3}$

In fact, the Sun King exploited the venal property of the magistrates without regard for their wealth and social position and without any inclination to treat them as political partners. On the question of venality, politics and the parlements, revisionism is wrong. To see what really happened, we must examine the two issues that had always threatened the venal interests of the judges: forced loans and the sale of new offices.

\section{Forced loans}

In 1664, Louis XIV created the East and West India Companies in an effort to challenge the Dutch and English for worldwide commercial supremacy. To capitalize the companies, the king obtained funds from the great nobles at court; and Colbert looked to the leading financial and judicial officials, such as the parlementaires. At Colbert's orders, the first presidents persuaded their colleagues to make India commitments ranging from several hundred livres from councillors to a thousand livres from présidents à mortier. The first presidents themselves pledged up to ten thousand livres apiece. The magistrates were to pay their pledges within five years, in three instalments; but as of 1669 most had missed one and some had missed all of their payments. ${ }^{4}$

To deal with this situation, the king declared, upon renewing the paulette in 1669, that all office-holders had to meet their India pledges before they could pay their annual paulette premiums. Significantly, some tribunals had to borrow money to meet this demand and bring their India payments up to date. The Parlement of Rennes, which had promised 90,000 livres, cleared its accounts by paying the king from the gages of its delinquents. But that was almost the least of the dilemma. The Parlement of Aix noted discerningly that an important principle, previously defended with success, was beginning to crumble, the principle that admission to the paulette should not depend upon the judges paying anything extra in advance. ${ }^{5}$ That warning soon came true.

When the paulette expired in 1674, the burgeoning Dutch War drove the government to exploit the India example more strongly than the Aix judges could have imagined. A declaration of October 1674 renewed the paulette for the customary nine years -1 January 1675 , to 31 December 1683 . But to obtain the paulette, a judge had first to pay for a substantial augmentations de gages; if he did not buy this augmentations de gages, the king would not accept his droit annuel, i.e. the annual paulette payment. Without the droit annuel, a magistrate could not count on preserving his office for his heirs. The king's demand for augmentations de gages raised the old question, recently articulated by the Parlement of Aix: whether the government could make the parlements pay extra money to get the paulette renewed. ${ }^{6}$ 
As the magistrates had virtually ceased to resist legislation, it seemed unlikely that they would refuse to pay this augmentations de gages. Even so, Colbert worried that unruly judges might make trouble of some kind, and he ordered the intendants to keep an eye on the parlements when they received the new declaration. In addition, he flatly denied a request from the Parlement of Rennes that he reduce the amount of money it was required to pay. All the parlements, he said, had to comply with the terms of the declaration, without negotiation or compromise. ${ }^{7}$

Colbert need not have worried, for the newly disciplined parlements quietly succumbed, registering intact an accompanying declaration that created the augmentations de gages and quietly paying the money demanded of them. ${ }^{8}$ At Montpellier, an amazed foreign visitor, John Locke, watched as magistrates of the local Chambre des Comptes, also covered by the paulette, submissively purchased their augmentations de gages: 'Otherwise they ... [would have] . . lost their places' ${ }^{9}$ He would have seen the same thing in any parlementary seat.

Under the new policy, a magistrate had to buy an augmentations de gages equal in value to his annual paulette, set at one-sixtieth of the appraised value of the office. Since office values differed significantly from one parlement to the next, the droit annuel and augmentations de gages varied in proportion. But all the judges determined how much money they needed for an augmentations de gages in exactly the same way. A lay councillor in the Parlement of Paris paid a droit annuel of four hundred livres and had to buy a 'salary increase' of the same amount. The capital he owed depended upon the interest rate, as fixed by Colbert. In 1674, perhaps still unsure of himself, Colbert set a generous rate of 7.14 percent, or what was known as the 14th denier. Our magistrate multiplied his paulette of 400 livres by 14 and found that he owed 5,600 livres, which at interest of 7.14 percent generated an augmentations de gages of 400 livres. Although magistrates in the provincial parlements paid somewhat less in augmentations de gages, this approach permitted Colbert to collect almost as much money overall as the highest sums his predecessors had tried but failed to get for the paulette renewals of the 1620 s and 1630 s. $^{10}$

Colbert's successors honoured his precedent and improved upon it. Every nine years, with the regularity of calendar intervals, in 1683, 1692 and 1701 , the king renewed the droit annuel on the terms that Colbert had established, with one significant change. In 1683 the government raised the denier from fourteen to eighteen; and the 18th denier became the standard, applied in 1692 and $1701 .{ }^{11}$ The new denier reduced Colbert's interest rate of 7.14 to 5.55 percent. With the denier 18 , a magistrate surrendered more capital but received the same augmentations de gages. Our magistrate multiplied his droit annuel by 18 instead of 14 and paid 7,200 livres instead of 5,600; the augmentations de gages stayed at 400 livres. Obviously the king collected a lot more money with the 18th than with the 14th denier, at no extra cost to his treasury. 
All the later renewals went very smoothly. When Colbert's hard-pressed successor, Claude Le Peletier, needed money in 1683, he unhesitatingly renewed the paulette in exchange for augmentations de gages capital, 'an immediate and considerable help', as he said himself. The parlements paid up even more quickly than in 1675, themselves forcing the few recalcitrant judges to disgorge. ${ }^{12}$ The next controller general, Louis Phélypeaux de Pontchartrain, demanded a new round of augmentations de gages when the paulette expired in 1692, justifiably confident that it would produce money he could immediately use in the War of the League of Augsburg, then in its fourth year. He assured First President Harlay that the Parlement of Paris would find the new augmentations de gages 'very agreeable', rhetorically turning an exaction into something of a favour. By 1701, when the king next renewed the paulette, the parlements had become so compliant that Controller General Chamillart referred to augmentations de gages as 'one of the most reliable methods for obtaining funds'. No finance minister under Richelieu or Mazarin could have made that statement. ${ }^{13}$

Whatever they said to the contrary, Colbert and his successors understood that the fear of losing their offices, rather than any prospective advantages, drove the judges to surrender their money. The third Chambre des Enquêtes of the Parlement of Paris confessed that it was paying for the augmentations de gages of 1692 so as 'not to put our offices at risk', a realistic assessment shared by all the judges. A controller general memorandum of 1708 acknowledged frankly that this blackmail alone made augmentations de gages so lucrative all during the reign. The policies of Louis XIV had deliberately placed the venal offices of the magistrates 'in jeopardy', it said. So far from abandoning that policy, Louis XIV adopted it and improved upon it, scooping up the substantial sums displayed in Table 1. ${ }^{14}$

As the numbers in this table show, the magistrates in the parlements paid more than 4.2 million livres in augmentations de gages in 1674, when Colbert granted them a high rate of interest ( 7.14 percent). When Le Peletier reduced the interest rate to 5.55 percent in 1683, he increased the yield of augmentations de gages to almost 5.5 million. By 1692, the addition of new judges to the parlements carried the total to more than 6 million livres, the peak year. In 1701, augmentations de gages declined a little, to 5.67 million, for several reasons. The Parlement of Bordeaux, having proved financial distress, persuaded the government to lower its augmentations de gages obligation by 50 percent, causing a drop in the overall total. In partial compensation, the Parlement of Metz, which had more magistrates in 1701 than in 1692, paid a bit more; and a new parlement, at Besançon, paid for the first time. (The Parlement of Tournai, also new, pleaded poverty and obtained an exemption.) These sums represented the financial consequences of the political submission of the parlements.

In 1689, Le Peletier 'invited' the parlements to volunteer for an extra aug- 
Table 1 Augmentations de gages per parlement, 1674-1701 (£)

\begin{tabular}{lrrrr}
\hline Parlement & \multicolumn{1}{c}{1674} & \multicolumn{1}{c}{1683} & \multicolumn{1}{c}{1692} & \multicolumn{1}{c}{1701} \\
\hline Paris & $1,284,458$ & $1,652,000$ & $1,819,200$ & $1,819,200$ \\
Bordeaux & 581,042 & 747,200 & 869,600 & 340,000 \\
Rennes & 552,720 & 711,600 & 760,800 & 760,800 \\
Rouen & 514,192 & 661,600 & 745,200 & 745,200 \\
Toulouse & 380,324 & 489,600 & 521,600 & 521,600 \\
Dijon & 310,464 & 400,000 & 435,200 & 435,200 \\
Grenoble & 224,672 & 289,200 & 306,000 & 306,000 \\
Aix & 179,634 & 231,600 & 270,000 & 270,000 \\
Metz & 176,316 & 227,200 & 244,800 & 254,800 \\
Pau & 58,338 & 75,200 & 152,000 & 152,000 \\
Besançon & & & & 71,225 \\
Tournai & & & & exempt \\
Totals & $4,262,160$ & $5,485,200$ & $6,124,400$ & $5,676,025$ \\
\hline
\end{tabular}

Source: This table is based upon BN, Cinq Cents Colbert, 259-260, 'États et évaluation par généralités, de tous les offices de judicature et finance (1665)', a general inventory of venal offices which enumerated the number and type of offices in each parlement and their paulette assessment. To produce Table 1, I simply multiplied the amount of the paulette each magistrate owed by the denier required for his augmentations de gages in the year indicated. This procedure assumes that each magistrate did pay his augmentations de gages, but this was overwhelmingly the case, as the AN, Series P, financial registers reveal. A study prepared in 1709 in the office of the controller general carried parlementary augmentations de gages of 1701 at 5,634,684 livres ('Estat général des offices ...', AN, G7, 1325), which is virtually the same as my figure of 5,676,025 livres. For the Parlement of Bordeaux, see AN, E 1810: decree of 29 December 1681, no. 141; AD, Gironde, B Parl.Arrêts., 8-12 August 1682 and 12 September 1701 .

mentatations de gages to help fund the onset of the War of the League of Augsburg. Since the current paulette ran through to 1692, Le Peletier could not connect the new augmentations de gages with the preservation of office and had to cajole rather than coerce the magistrates into submission. The precedents for voluntary loans offered little hope for success, but Le Peletier approached the Parlement of Paris optimistically, determined to improve upon the past. Negotiations elicited a promise of one million livres for the new augmentations de gages, another sign of First President Harlay's fealty to the government. As soon as the Parlement of Paris had agreed to pay, Le Peletier used its example to 
persuade the provincial tribunals that it was their turn to step forward. ${ }^{15}$ Under Louis XIII, a finance minister would have found this a hard job, but times had clearly changed. Most provincial tribunals compliantly promised to pay from 200,000 to 300,000 livres, with tiny Pau settling on 54,000 livres. In sum, the controller general collected an unscheduled 3.15 million livres from the parlements with no more effort than it took him to get the client Harlay to cooperate and then to write a circular letter to the provincial tribunals. Table 2 shows how much each parlement contributed.

Table 2 Augmentations de gages of 1689

\begin{tabular}{lr}
\hline Paris & $1,000,000$ \\
Aix & 200,000 \\
Bordeaux & 300,000 \\
Dijon & 200,000 \\
Grenoble & 200,000 \\
Metz & 200,000 \\
Pau & 54,000 \\
Rennes & 300,000 \\
Rouen & 250,000 \\
Toulouse & 250,000 \\
Besancon & 100,000 \\
Tournai & 100,000 \\
& \\
Total & $3,154,000$ \\
\hline
\end{tabular}

Source: Paris: BN, Fonds fr., 19,769: 'Estat des affaires extraordinaires . . ', f. 12r; Aix: Le Bret, first president, to Pontchartrain, controller general, 8 April 1693, AN, G7, 462; Bordeaux: Arguier, commis, to Chamillart, controller general, 7 March 1702, AN, G7, 139; Dijon: BM, MS 769 (Registres du Parlement): 28 January 1690, p. 2, and AN, E 1859: decree of 18 April 1690; Grenoble: $\mathrm{AD}$, Isère, 2B4* (... les finances du Parlement . . .'), f. 272rv; Metz: AD, Moselle, B 308 (Registres secrets): 17 August 1689 (f. 9r) and 13 September 1689 (ff. 19v-21v); Pau: AD, P-A, B 4541 (Registres secrets): 22 August and 19 September 1689 and 26 and 28 February 1690; Rennes: AD, I-V, IBb (Registres secrets) 273: 12 September 1689, f. 15; Rouen: Chamillart, intendant, to Pontchartrain, 21 December 1689, AN, G7, 493; Toulouse: Morant, first president, to Pontchartrain, 26 March 1692, AN, G7, 300; Besançon: AN, E 1860: 7 January 1690; Tournai: Bagnols, intendant, to Pontchartrain, 27 January 1691, AN, G7, 258. 
In a paulette year the government also collected augmentations de gages capital from the seven chambres des comptes (3.9 million livres), the four cours des aides (660,000 livres), the two cours des monnaies $(197,000)$, and the Grand Conseil $(386,000)$. A study prepared for the controller general in 1709 showed that augmentations de gages collected in 1701 from all the superior courts came to almost 10.8 million livres, of which the parlements paid 52 percent. Other studies, prepared with a somewhat different statistical base, listed totals as high as 13.2 or 14.4 million livres. With contributions from the lower magistracy, the grand total for an augmentations de gages rose to about twenty million livres, a significant sum in an annual war budget of about one hundred million livres. One may reasonably suppose that when the parlements paid their augmentations de gages, it was easier for the government to collect them from everybody else. $^{16}$

In 1683, 1692 and 1701, a président à mortier in the Parlement of Paris remitted 20,000 livres for augmentations de gages and a lay councillor, 7,200 livres; and many provincial judges paid almost as much. Until the government halved their obligations in 1701, the magistrates of Bordeaux paid at the levels of Paris: 18,000 livres for a président à mortier and 7,200 livres for a lay councillor. Also in the provincial upper ranks, at Rennes and Rouen, the présidents à mortier disbursed 10,800 and 14,400 respectively, and the councillors, 6,400 (Rennes) and 6,000 (Rouen). In the parlements in the financial middle, présidents à mortier spent 8,400 (Grenoble), 8,000 (Toulouse and Dijon), 7,200 (Aix) and 4,000 (Metz), while lay councillors laid out 4,800 (Dijon), 4,000 (Toulouse and Grenoble), 3,000 (Aix) and 2,400 (Metz) respectively.

But what did these sums mean to the private wealth of a particular judge? In the Parlement of Brittany, to begin with a provincial tribunal, the mean fortune of record was 283,800 livres, a figure derived from twenty-three fortunes reconstituted in full from among the 331 magistrates who held office in the reign. To be sure, the Breton judges included a couple of millionaires, and a few with fortunes of more than 500,000 livres. But the wealth of the majority ranged from 150,000 to 350,000 livres; and these fortunes congregated at the lower end of that scale. This spectrum of wealth seems valid also for Aix and Toulouse and probably applies to the provincial magistracy as a whole. Evidence for the wealth of the magistrates of the Parlement of Paris shows that most of their fortunes, though somewhat larger than those of the provincials, still fit within this range of 150,000 to 350,000 livres, with more of a bias towards the upper limit. ${ }^{17}$

Fortunes such as these provided a comfortable living standard, certainly in relation to that of the general population, but we should not think of the magistrates as an opulent group who could readily afford augmentations de gages. The wealthy elite aside, most judges had little financial room in which to manoeuvre. Since their wealth consisted largely of land and venal office, which generated returns of about 3 percent of capital, the majority of the 
judges had incomes of 4,000 to 9,000 livres. At 9,000 livres, judges could have supported their families without much difficulty in all the parlementary cities, including Paris. But most magistrates probably took in something closer to 5,000 livres, since income from venal office diminished sharply after about 1675 and income from land also suffered stagnation and then decline. Moreover, all their incomes, like those of the nobility in general, had to bear a variety of fixed expenses, such as the interest on debts incurred to pay for the office or portions owed to heirs as part of marriage or family settlements. Most judges found themselves financially encumbered all during their careers and needed to plan carefully to maintain themselves and their families in a dignified way. Since augmentations de gages payments ran from 2,400 livres for a councillor in Metz to 20,000 livres for a président à mortier in Paris, the majority could not pay for augmentations de gages from their annual incomes. They had to borrow. ${ }^{18}$

So great were their needs that they soon overwhelmed the traditional resources of patrons, family and colleagues and had to compete for funds on the credit market, with the mediating help of notaries. Notaries, familiar with the secrets of property settlements and inheritance, knew where to find money. They put the judges in touch with lenders for the augmentations de gages of 1683,1692 and $1701 .^{19}$

Sometimes an entire tribunal borrowed the money collectively, pleasing the controller general by paying everything it owed in a lump sum. In this case, a parlement appointed trusted magistrates to negotiate the loans; and these officials filed a procuration, or power of attorney, with one or more notaries in the parlement's seat and perhaps also with notaries in Paris. The Parlements of Aix and Dijon often proceeded this way, usually raising the capital they needed within months. As interest on their money, the lenders received the augmentations de gages of that parlement, year by year, directly from its paymaster (payeur des gages). ${ }^{20}$

More generally, however, magistrates borrowed as individuals, first seeking funds from family and friends before trusting themselves to notaries. Individual borrowing prevailed at Bordeaux, Grenoble, Metz, Rennes, Rouen, Toulouse and in some chambers of the Parlement of Paris. This method required each parlement to push individual magistrates to conclude their personal loans promptly in order to meet the augmentations de gages deadline, but all the tribunals lived up to that responsibility. For example, the Parlement of Rennes, once a rock of fiscal resistance, now wrote threatening letters to tardy magistrates to demand that they pay on schedule. ${ }^{21}$

The government ensured the confidence of lenders by providing them with sound collateral - the very offices of the judges. Under the augmentations de gages edicts of 1683, 1692 and 1701, a lender obtained a 'privileged mortgage' on the office of the borrower. Such a mortgage entitled the lender, in case of default, to be repaid in full, before all other claimants, because he or she had lent 
money for the sake of preserving the office, an obvious priority. ${ }^{22}$ An edict of February 1683 reaffirmed the primacy of the privileged mortgage and laid out procedures by which creditors who held it could seize an office, instilling lenders with even more confidence. ${ }^{23}$

Foreclosure was already an occupational hazard for office-holders. Magistrates who had purchased their offices usually had to borrow heavily, and even judges who inherited their offices were likely to have inherited ancient debts too. Many walked a financial tightrope, and by no means all kept their balance. In the 1690s and early 1700s, creditors routinely seized offices of delinquent judges in the Parlements of Bordeaux and Rennes, among others. In 1709, Chancellor Pontchartrain, declaring that the 1683 edict must be 'executed to the letter', ruled in favour of creditors who wanted to seize the office of a debt-ridden councillor in the Parlement of Bordeaux, despite his many years of service. In assuming new debts in order to pay for their augmentations de gages, the magistrates therefore exposed their offices to creditors more than they had ever done. ${ }^{24}$

On a positive note, Louis XIV, in contrast with his predecessors, paid augmentations de gages faithfully, year by year and quarter by quarter, to the satisfaction of both the magistrates and their creditors. In the early 1660s, Colbert had repudiated some augmentations de gages, despite indignation in the Parlement of Paris; but when the Dutch War ended, he refunded the augmentations de gages of 1674 in full and in a lump sum. This permitted the magistrates to reimburse their creditors and increased the confidence of the latter in augmentations de gages loans. ${ }^{25}$

At the end of the War of the League of Augsburg, however, the king could no longer refund the capital paid for the augmentations de gages of 1683, 1689 and 1692 and did not wish to continue paying the loans at the full rate. Controller General Chamillart did not even consider repudiation, so numerous had the parlements' creditors become. To lighten royal expenses, he unilaterally reduced the interest on augmentations de gages from denier 18 (5.55 percent) to denier 20 (5 percent) and took the risk of an outcry in the parlements. But they all accepted this reduction in an apparent show of good will, utterly insincere since the king left the judges to pay their creditors the original interest rate. This reduction, however troublesome, was nevertheless considerably better than repudiation, apparently consigned once and for all to the past. $^{26}$

In sum, Louis XIV repeatedly demonstrated his power to extract loans from the parlements as a requirement for admission to the paulette, a royal breakthrough on a previously vexed issue. As long as the magistrates could borrow money, however, and the king paid the augmentations de gages reliably, the judges suffered more politically than financially, a recurring sign of their subordination. It was only worrisome that at least every nine years they sank more deeply into debt, their offices more heavily mortgaged. ${ }^{27}$ 


\section{The sale of offices}

Offices in the parlements increased in value from the sixteenth into the middle decades of the seventeenth century. The price of a councillor office in the Parlement of Paris rose from about 11,000 livres in 1597 to 120,000 livres in 1637 , an astonishing gain of some 1,200 percent in only forty years. In the Parlement of Rouen, the office of councillor shot up from 7,000 livres in 1593 to 84,000 in 1633 , a proportionately similar increase. The office creations under Louis XIII may have slowed, but they did not stop this upward march, the fears of the magistrates notwithstanding. In Aix, the councillor office increased from a range of 3,000-6,000 livres around 1610 to 50,000 in 1633 and then pushed up to 81,000 , as of 1659 . In the Parlement of Rennes, the councillor office attained 100,000 livres in the 1630s and soared to a peak of 187,000 livres in the early 1660 s. Office values probably rose comparably in the other parlements. When Louis XIV began to rule, offices formed the largest single component of the private wealth of many judges, making them more sensitive than ever to any changes in venality. ${ }^{28}$

Although Louis XIV might have emulated his predecessors and tried to create new offices in the parlements, suppressing as he could whatever opposition they proffered, instead he began his personal rule by trying to reform venality. In 1610, Loyseau had coined the satirical word 'archomania' to describe the maniacal quest for any sort of venal office, with little regard for its functions or inherent value. Authors, royal ministers and the Estates General in its periodic sessions had all condemned venality for absorbing investment capital to the detriment of economic growth. Monarchs from Charles VIII to Henry III pledged at least to reduce the number of venal offices, without ever living up to their promises. So Louis XIV inherited both an abundance of venal offices and an ongoing demand to get rid of them. ${ }^{29}$

An inventory commissioned by Colbert in 1665 listed 45,780 venal offices in the kingdom, carrying an estimated value of almost 420 million livres, with offices in the parlements among the costliest in the realm, the ripe fruit of archomania. This inventory served as the basis for proposals for the reform of venality, which Colbert brought to the king and the Council of Justice. In December 1665, the Council produced reform edicts for the Parlement of Paris and the provincial tribunals. Under these edicts, the king extended the paulette for only three years instead of the customary nine and announced his intention to terminate it in the future. He also imposed price controls on offices in the parlements, setting a fixation or ceiling that buyers and sellers were not to exceed, upon pain of losing the office. The edicts declared the king's intent to suppress venal offices as his finances permitted, redeeming them at fixation prices, set somewhat below market values. In sum, the edicts of December 1665 brought office prices down at once in order to make it cheaper to redeem offices in the future, meanwhile announcing the approaching end of the paulette. Although very different from 
forced loans and office creations, their traditional worries, the reforms posed an obvious threat to the venal interests of the magistrates. ${ }^{30}$

Colbert's inventory somewhat underestimated office prices in the parlements; and we can correct his list with real pre-1665 values in only a few cases. Figures for the fixation levels are also in short supply. Based on the information at hand, however, it is reasonably clear that Colbert intended to reduce prices in the parlements by about 15 to 20 percent, obliging office-holders to absorb the losses without compensation. Because prices were somewhat higher than he believed, he was actually threatening to reduce values by around 30 percent, all the harder to bear. This explains the hostile reception the fixation edict met in the parlements. Tensions in the Parlement of Paris rose steeply after the king registered it in a lit de justice. The Parlements of Rouen and Aix sent firm letters of protest, and the Parlements of Bordeaux and Rennes issued strongly worded remonstrances. All objected to the low values in the fixation, and the remonstrance of Rennes deplored what it saw as the impending socio-economic collapse of the entire magistracy. The reform edict alone makes clear that Louis XIV and Colbert had little concern for protecting the material interests of the parlementaires. $^{31}$

In fairness, the immediate effects of the fixation edict were not as dire as the magistrates predicted. Sellers of office could escape the price limits by pressuring buyers to give them extra money under the table, a payment called a pot de vin. For example, Ormesson boasted in his journal that when he sold his office of master of requests he covertly received 84,000 livres above the fixation of 150,000 livres, a financial coup. When, in 1679, the Breton magistrate Berthou de Kerverzio purchased an office of président aux Requêtes, he noted privately that he paid 108,000 livres for it, well above the fixation of 90,000 livres stipulated in the contract. We can assume that many judges skirted the fixation in exactly the same way. ${ }^{32}$

Since buyers and sellers could evade the price ceilings, revisionist historians have concluded that the attempted reform did them little damage; but it must be noted that the government knew about evasions of the fixation and worked to curb them. An edict of March 1669 ordered the treasurer of the parties casuelles, the clearing house for venality, to approve office sales only when he knew that buyer and seller had obeyed the fixation. A successor declaration of November 1671 attempted to strengthen enforcement by requiring a buyer of office to deposit with the parties casuelles the sum he had agreed to pay the seller. When officials assured themselves that the negotiated price did not exceed the fixation, they paid the deposit to the seller, reducing the possibility that the latter could extract a pot de vin. ${ }^{33}$

Of course, the deposit requirement could not altogether suppress the private arrangements by which individuals circumvented the fixation, as Berthou proved in 1679; but it seems to have had some effect. Ormesson, who had triumphed earlier in the sale of his office, noted in 1671-1672 that the deposit 
had improved enforcement of the fixation significantly. The government's files refer to it through the 1680s, proving that it never wholly lapsed, like so many reform projects in the past. Nor should we assume that large numbers of buyers were anxiously eager to exceed the ceilings. In 1673, the heirs of the deceased Breton président à mortier Brie petitioned the royal council for more time to sell his office: no one had offered even the fixation price, they declared. ${ }^{34}$

Even more important, the fixation ended once and for all the price rise that had begun in the late sixteenth century. If immediately after 1665 a magistrate could still, through subterfuge, sell his office for more than its legal price, he could not reasonably hope that a regulated market, with its psychology of restraints and evasions, would generate the strong capital gains of the preceding decades. By 1690 prices had fallen in almost every parlement. It is logically possible, although empirically unlikely, that the halt in price increases and then the actual decline merely coincided with, and was not caused by, the price regulations of Louis XIV. But common sense tells us that the edict of December 1665 contributed powerfully to ending an era of capital appreciation upon which, significantly, the magistrates depended to make their offices profitable during their years in office. ${ }^{35}$ However imperfectly obeyed in the short term, the reform edict ultimately damaged the interests of the magistrates.

The Dutch War obliged Colbert to abandon his plans to reform venality. The paulette could not be suppressed, since augmentations de gages depended upon it, nor could offices be redeemed. Like his predecessors, Colbert had to sell new venal offices in great quantity. He created clerks and minor officials in all the law courts and doubled the number of judges in the Châtelet, a civil and criminal tribunal in Paris. A vast number of small merchants found themselves, like solicitors in the 1660s, turned into holders of venal office. But Colbert seems never to have considered selling new offices of president and councillor in the parlements, which would have yielded more money than all of these. Some scholars have supposed that the parlements remained free of office creations all during the reign, which, if true, would have compensated the judges for the effects of the 1665 edict. However, their immunity on this point did not much outlive Colbert himself. ${ }^{36}$

The need to finance the War of the League of Augsburg (1689-1697) and the War of the Spanish Succession (1702-1713/1714) obliged Colbert's successors to create venal offices in the thousands and to extend venality into the recently acquired province of Franche-Comté. Not since the 1630s, under Richelieu, had new, and increasingly artificial, offices rained down upon the kingdom in such profusion. Venality, which Louis XIV had earlier tried to curtail, approached its extreme limits. ${ }^{37}$ Inevitably the government resumed selling new offices in the parlements, abandoning what was left of Colbert's reform agenda. Just as they could not resist augmentations de gages, the tribunals could no longer ward off increases in their numbers. Freed from the restraints that had hobbled his predecessors, Louis XIV sold new offices in the 
parlements to the degree that the market would bear, with scarcely a trace of opposition.

In September 1689, Phélypeaux de Pontchartrain, the former first president of the Parlement of Rennes, replaced Le Peletier as controller general and lifted Colbert's ban on creating parlementary offices. He started with the Parlements of Rennes and Bordeaux, still suffering their respective exiles for a lack of zeal in suppressing the uprisings of 1675. In October, accepting Pontchartrain's advice, the king issued an edict creating in the Breton tribunal a new président à mortier, four originaire councillors, and two non-originaire councillors, for a total of 550,000 livres. Pontchartrain made clear that the tribunal would have to accept this package if it wanted to return home. The municipality of Rennes added about 500,000 livres, bringing the full ransom up to more than 1 million livres; but, having paid the price, the Parlement resumed work in Rennes in 1690, after an exile of more than fourteen years. ${ }^{38} \mathrm{~A}$ similar pay-off returned the Parlement of Bordeaux to its capital, also in 1690. The Bordeaux tribunal agreed to the creation of a président à mortier and six councillors, all for 320,000 livres; and the city government accepted enough extra taxes to carry the total to the required 1 million. ${ }^{39}$ These office creations, significant in their own right, prepared the way for a wave of new offices that soon swept over every other parlement in the realm.

In the Parlement of Paris, an edict of November 1690 created two présidents à mortier, sixteen councillors, and one avocat général - the largest sale of new offices in that tribunal in the century and the most lucrative, producing 2.85 million livres for the king. In 1691, office creations in Toulouse, Rouen, Dijon, Metz and Pau added thirty-five provincial judges, totalling another 2 million livres, while creations of four judges in Grenoble in 1692 and of nine in Aix in 1693 brought in 362,000 and 580,000 livres respectively. Follow-up sales took place in Metz in 1694 and 1695. The government sold the offices in the Parlement of Paris without the intercession of traitants, and thus netted all the 2.85 million livres that the new magistrates paid in. Traitants financed the sale of the provincial offices, collecting the conventional remise en dedans, or commission, of 16.7 percent (i.e. one-sixth the gross value); with that deduction, the provincial sales netted the government 3.35 millions. In summary, the government created 92 new judges in all these parlements between 1689 and 1692, increasing their numbers by 9.12 percent and gaining 6.2 million livres. $^{40}$

During the Augsburg war, the king also 'converted' to venality the judges in the newly established Parlements of Besançon and Tournai, who had previously held their posts as royal appointees. ${ }^{41}$ Except for the first presidents and the procureurs généraux, the forty sitting judges in Besançon and the twenty-five in Tournai had to purchase the offices that they currently occupied. The king also added eighteen new magistrates to the Parlement of Besançon and seven to the Parlement of Tournai, putting those offices for sale on the open market. 
Adapting themselves to venality cost the sitting judges about 1 million livres, and the new magistrates together paid some 500,000 livres for their posts. Deducting the remise for the traitants, the net for the government was probably 1.28 million livres (see Table 5). These operations added another eighty-seven venality judges to the ranks of the parlementaires.

In total, Louis XIV and Pontchartrain increased the number of venality judges in the parlements by 179 , a rise of 17.75 percent from the 1665 base of 1,008 magistrates, certainly the largest proportional increase in parlementary numbers since the reign of Henry III. The king earned almost 7.5 million livres from selling offices in the older parlements and by extending venality to Besançon and Tournai. This was probably the most profitable sale of new offices in the parlements that had ever taken place.

In contrast with their predecessors, the parlements of the 1690s did not protest, delay or obstruct registration of the office edicts and did nothing to interfere with the ensuing sales. The 1673 requirements for the registration of new laws all but ensured that everything would go well. For example, the edict creating new offices in the Parlement of Paris bore the date of November 1690; the Parlement registered it on 23 November. On 4 April 1691, the Parlement of Dijon registered the edict of March 1691 that created new offices there. The Parlement of Aix registered its creation edict, dated June 1693, on 19 June. Most first presidents could report, as did Morant from Toulouse, a 'perfect submission' in registering edicts for new offices. When the Parlement of Grenoble resisted a bit, Pontchartrain threatened to create a new subordinate law court, a présidial, and award it some of the Parlement's jurisdiction; the tribunal capitulated at once. ${ }^{42}$

In most parlements, the office sales proceeded smoothly and with reasonable speed. The new magistrates in the Parlement of Dijon took their seats between 13 June 1691 and 25 March 1692. The sales in Aix, Grenoble, Metz, Rennes and without doubt Paris also met with no obstacles. The sitting judges in Besançon and Tournai, who were obliged to purchase their offices, needed time to find the money; but the new offices in those parlements all found owners soon enough. ${ }^{43}$

Offices sold somewhat more slowly in the Parlements of Toulouse and Bordeaux, where economic conditions depressed the market; but the sitting judges offered no resistance to the newcomers. Of the five new offices created in Toulouse by the edict of February 1691, two remained unsold as of November 1693, despite the best efforts of Morant and the intendant Lamoignon de Bâville. Four of the six councillor offices created in Bordeaux sold rather quickly, as did the président à mortier; but it took more than a year before buyers for the last two councillor offices appeared.

Things went even more slowly in Rouen, where the edict of March 1691 created eleven new offices, including seven lay councillors, the largest expansion of any of the older provincial tribunals except Metz. Only three of the seven 
councillor offices sold by the end of 1691; and no buyers appeared for either of the two new présidents à mortier, which may not have sold until the late 1690s. Like Bordeaux and Toulouse, however, Rouen suffered from a scarcity of buyers, not from political obstruction. ${ }^{44}$

Indeed, the sitting judges had every reason to help sales along, since they suffered personally from any delay. When it created new offices, the government banned current owners from selling their posts and arrogated to itself the entire market, strong or weak. Otherwise the king would have found himself in a price war with local owners, an absurdity. Since a majority of the new offices sold within a year, the inconvenience did not last long; but it harmed the interests of would-be sellers of office while it was in place. If the new sales took more than a year, as they did in Bordeaux and Rouen, a growing number of magistrates experienced not only inconvenience but also financial distress. In Bordeaux, eight offices were already up for sale when the new offices appeared on the market; and those aspiring sellers had to wait many additional months before they could search for buyers, whereupon they found that the king's new offices had more than satisfied all demand. In Rouen, three or four offices normally changed hands annually; but because the sale of new offices proceeded slowly through the 1690s, a substantial backlog of old offices built up there, year by year, to the economic discomfort of established parlementary families. ${ }^{45}$

The king's sale of new offices came at an unfortunate time for all the tribunals. By the 1690s, office prices in the parlements had largely declined to, or fallen below, their fixation levels of 1665; and the new offices, by adding to the supply, kept prices down. Except for the office of président à mortier in the Parlements of Paris and Dijon, the venal market had softened everywhere. In 1690, the councillor office in Paris had descended to its fixation of 100,000 livres, as had the président à mortier in Toulouse, to 120,000 livres. The councillor offices in the provinces were sinking beneath the fixation, with declines of 15 percent in Rennes and Bordeaux and of almost 50 percent in Toulouse. Because Colbert had set the fixation below what he thought were true market values, the data in Table 3 somewhat understate the loss of capital since 1665.

In general, venal offices in these parlements had declined by 17 to 58 percent from the price levels in the inventory for 1665 and probably by another 10 to 20 percent from pre-1665 market prices. With the exception of Paris, all these parlements saw prices falling below Colbert's fixations. Other parlements had certainly suffered similar losses. Under Louis XIII, the parlements often complained, needlessly, that the appearance of new offices on the market would cause existing offices to decline in value. But this supply-and-demand truism applied in full to the economics of office under Louis XIV. Having saturated the markets, the new offices continued to depress prices for years to come, as Controller General Chamillart frankly acknowledged in $1702 .{ }^{46}$

Hoping to move office sales along, the government added the occasional sales incentive, in the form of one concession or another. But the controller 
Table 3 Office prices in selected parlements, 1665-1690s

\begin{tabular}{lcccc}
\hline $\begin{array}{l}\text { Parlement } \\
\text { office }\end{array}$ & $\begin{array}{c}\text { Inventory } \\
\text { price }\end{array}$ & $\begin{array}{c}\text { Fixation } \\
\text { price }\end{array}$ & $\begin{array}{c}1690 \mathrm{~s} \\
\text { price }\end{array}$ & $\begin{array}{c}\text { Inventory/sale } \\
\text { difference (\%) }\end{array}$ \\
\hline Paris & & & & N/A \\
PM & 500,000 & 350,000 & 500,000 & -17 \\
C (L) & 120,000 & 100,000 & 100,000 & -22 \\
Rennes & & & & -33 \\
PM & 180,000 & 150,000 & 140,000 & -25 \\
C (O) & 120,000 & 100,000 & 80,000 & \\
C (NO) & 60,000 & 70,000 & 45,000 & -47 \\
Bordeaux & & & & -33 \\
PM & 150,000 & 120,000 & 80,000 & \\
C (L) & 60,000 & 50,000 & 40,000 & -20 \\
Toulouse & & & & -58 \\
PM & 150,000 & 120,000 & 120,000 & \\
C (L) & 83,000 & 60,000 & 35,000 & \\
\hline
\end{tabular}

Abbreviations: PM: président à mortier; C: councillor; (L): lay councillor; (C): clerical councillor; (0) and (NO): originaire, or Breton, and non-originaire, or non-Breton, councillor, Rennes.

Source: The documentation for this table is in Table 4.

general yielded nothing of substance, nor did he find it necessary to appease the tribunals on all points. For example, magistrates of the Parlement of Paris recovered the privilege of nobility in the first degree, revoked by the king in 1669; but First President Harlay regarded this restoration as purely honorific. Most of his magistrates had already lifted themselves into the nobility, their fathers and grandfathers having held parlementary office before them, the standard two-generation ennobling procedure. ${ }^{47}$ Moreover, the government did not extend the privilege to the provincial tribunals, even when they asked for it. The Parlement of Dijon requested first degree nobility along with financial and jurisdictional concessions: ' . . we have refused all the demands of the Parlement of Dijon', read a brusque note on the Parlement's supplicating letter to the controller general. When First President Faucon de Ris of Rouen also asked for first degree nobility for his tribunal, he met with an identical rebuff. ${ }^{48}$

As for modest concessions, a parlement might be allowed to revise its internal organization and procedures; or the government might promise that the royal council would show greater restraint in transferring lawsuits from one parlement to another, easing an old parlementary grievance. The king might also grant dispensations from the minimum-age requirements for office (twenty-five for councillors) or the restrictions on the number of judges in a tri- 
bunal who could be related by birth or by marriage. But it had always conferred these dispensations, upon petition by individuals, and kept general concessions to a minimum. ${ }^{49}$

The government might have revoked the fixation, to which the parlements had objected so strenuously when Colbert imposed it in 1665. After all, higher prices now served the king's financial interests. The creation edict of October 1689 for the Parlement of Rennes indeed terminated the fixation for that tribunal and restored the free market for offices there, and the Parlement of Bordeaux got the same concession. The controller general considered ending the fixation for the Parlement of Paris but chose instead to rescind only the deposit requirement, not the fixation itself, for reasons that he never explained. So Colbert's principle of price ceilings, although weakened, remained nominally in place except in Rennes and Bordeaux (where office prices declined anyway, all through the 1690s). Accommodation, even when it made sense, went only so far. ${ }^{50}$

Unlike most of the concessions to which Louis XIII had eventually agreed, those of Louis XIV did not deprive the government of any money it expected from the sale of office. If a parlement preferred, the government would create more or fewer councillor offices, as opposed to présidents à mortier, shuffling offices from one category to the other. But a parlement could not hope to reduce the final sum that Pontchartrain, in consultation with the intendants, had decided that the sale should produce. As he informed the Parlement of Rennes in 1689, '... the king has decided that he wants 500,000 livres ... [and] leaves it up to you to choose the means'.

A parlement could avoid an office creation only by paying the government the money it wanted in a lump sum, as a 'redemption'. The Parlement of Grenoble redeemed a few offices in this way; and the Parlement of Aix even scored a financial coup. In June 1693, the king created two présidents à mortier, six councillors and one procureur général at Aix; the sale was expected to gross 580,000 livres. But in July the king accepted a redemption offer of 440,000 livres from the Parlement, payable in three equal instalments over eighteen months. The difference between those sums was about equal to the commission of the traitants, a portion of which the Parlement also paid as a supplement, so the government lost nothing on the transaction and the traitants gained some compensation. The Parlement sold all the offices itself in one of the few markets where demand was still strong and made a profit of more than 100,000 livres, much of which it used to retire debt for the augmentations de gages of 1692! But while the Parlement of Aix actually profited from the sale of offices, no other tribunal enjoyed a comparable success. ${ }^{51}$

\section{Summary}

From the administration of Colbert through to that of Pontchartrain, the government steadily encroached upon the vested interests of the magistrates 
Table 4 Sale of new offices in parlements, 1689-1695

\begin{tabular}{|c|c|c|c|c|c|c|}
\hline Office & $\begin{array}{l}\text { Judges } \\
1665\end{array}$ & $\begin{array}{l}\text { New } \\
\text { offices }\end{array}$ & $\begin{array}{l}\text { Price per } \\
\text { office }(£)\end{array}$ & $\begin{array}{c}\text { Total } \\
\text { sales }(f)\end{array}$ & $\begin{array}{c}\text { Judges } \\
1695\end{array}$ & $\begin{array}{c}\% \text { Incr. } \\
\text { from sales }\end{array}$ \\
\hline Oct. 1689 & Rennes & & & & & \\
\hline PP & 1 & & & & 1 & \\
\hline PM & 7 & 1 & 140,000 & 140,000 & 8 & 14.29 \\
\hline $\mathrm{PE}$ & 4 & & & & 4 & \\
\hline $\mathrm{C}(\mathrm{O})$ & 40 & 4 & 80,000 & 320,000 & 44 & 10.00 \\
\hline $\mathrm{C}(\mathrm{N})$ & 40 & 2 & 45,000 & 90,000 & 42 & 5.00 \\
\hline PR & 2 & & & & 2 & \\
\hline $\mathrm{CR}$ & 10 & & & & 10 & \\
\hline AG & 2 & & & & 2 & \\
\hline PG & 1 & & & & 1 & \\
\hline Totals & 107 & 7 & & 550,000 & 114 & 6.54 \\
\hline
\end{tabular}

Sep. 1690 Bordeaux

$\begin{array}{lrrrrrr}\text { PP } & 1 & & & & 1 & \\ \text { PM } & 7 & 1 & 80,000 & 80,000 & 9 & 12.50 \\ \text { PE } & 4 & & & & 4 & \\ \text { CH } & 0 & & & & 0 & \\ \text { C(L) } & 65 & 6 & 40,000 & 240,000 & 77 & 8.45 \\ \text { C(C) } & 7 & & & 7 & \\ \text { PR } & 2 & & & & 2 & \\ \text { CR } & 8 & & & & 8 & \\ \text { AG } & 2 & & & & 2 & \\ \text { PG } & 1 & & & 1 & \\ \text { Totals } & 97 & 7 & & 320,000 & 111 & 6.73\end{array}$

Nov. 1690 Paris

$\begin{array}{lrrrrrr}\text { PP } & 1 & & & & 1 & \\ \text { PM } & 7 & 2 & 450,000 & 900,000 & 9 & 28.57 \\ \text { PE } & 10 & & & & 10 & \\ \text { C(L) } & 162 & 16 & 100,000 & 1,600,000 & 178 & 9.88 \\ \text { C(C) } & 22 & & & & 22 & \\ \text { PR } & 4 & & & & 4 & \\ \text { CR } & 28 & & & & 28 & \\ \text { AG } & 2 & 1 & 350,000 & 350,000 & 3 & 50.00 \\ \text { PG } & 1 & & & & 1 & \\ \text { Totals } & 237 & 19 & & 2,850,000 & 256 & 8.02\end{array}$

Feb. 1691 Toulouse

$\begin{array}{lllllll}\mathrm{PP} & 1 & & & 1 & \\ \mathrm{PM} & 6 & 2 & 120,000 & 240,000 & 9 & 28.57 \\ & & & & & \\ & & & & & \\ & & & & \end{array}$


Table 4 (cont.)

\begin{tabular}{lrcccrr}
\hline Office & $\begin{array}{r}\text { Judges } \\
1665\end{array}$ & $\begin{array}{c}\text { New } \\
\text { offices }\end{array}$ & $\begin{array}{c}\text { Price per } \\
\text { office }(f)\end{array}$ & $\begin{array}{c}\text { Total } \\
\text { sales }(f)\end{array}$ & $\begin{array}{r}\text { Judges } \\
1695\end{array}$ & $\begin{array}{c}\text { \% Incr. } \\
\text { from sales }\end{array}$ \\
\hline Feb. 1691 & Toulouse (cont.) & & & & & \\
PE & 4 & & & & 6 & 50.00 \\
C(L) & 93 & 2 & 35,000 & 70,000 & 93 & \\
C(C) & 6 & & & & 6 & \\
PR & 2 & & & & 2 & \\
CR & 11 & 1 & 25,000 & 25,000 & 12 & \\
AG & 2 & & & & 1 & \\
PG & 1 & & & & & \\
commissions of & & 2 & 30,000 & 60,000 & & \\
Pres. Enquêtes & & & & & & \\
Totals & 126 & 5 & & 395,000 & 132 & 4.76
\end{tabular}

Mar. 1691 Rouen

$\begin{array}{lrrrrrr}\text { PP } & 1 & & & & 1 & \\ \text { PM } & 7 & 2 & 150,000 & 300,000 & 9 & 28.57 \\ \text { C(L) } & 66 & 7 & 50,000 & 350,000 & 73 & 10.61 \\ \text { C(C) } & 17 & & & & 17 & \\ \text { PR } & 2 & & & & 2 & \\ \text { CR } & 12 & 2 & 30,000 & 60,000 & 14 & 16.67 \\ \text { AG } & 2 & & & & 2 & \\ \text { PG } & 1 & & & & 1 & \\ \text { Totals } & 108 & 11 & & 710,000 & 119 & 10.19\end{array}$

Mar. 1691 Dijon

$\begin{array}{lrrrrrr}\text { PP } & 1 & & & & 1 & \\ \text { PM } & 8 & 2 & 130,000 & 260,000 & 10 & 25.00 \\ \text { CH } & 2 & & & & 2 & \\ \text { C(L) } & 51 & 3 & 66,000 & 198,000 & 54 & 5.88 \\ \text { C(C) } & 5 & & & & 5 & \\ \text { PR } & 2 & & & & 2 & \\ \text { CR } & 9 & 1 & 45,000 & 45,000 & 10 & 11.11 \\ \text { AG } & 2 & & & & 2 & \\ \text { PG } & 1 & & & & 1 & \\ \text { Totals } & 81 & 6 & & 503,000 & 87 & 7.41\end{array}$

May 1691, Mar. 1694, Nov. 1695 Metz

$\begin{array}{lrrrrrr}\text { PP } & 1 & & & & 1 & \\ \text { PM } & 10 & 2 & 50,000 & 100,000 & 12 & 20.00 \\ \text { CH } & 2 & & & & 2 & \end{array}$


Table 4 (cont.)

\begin{tabular}{|c|c|c|c|c|c|c|}
\hline Office & $\begin{array}{c}\text { Judges } \\
1665\end{array}$ & $\begin{array}{l}\text { New } \\
\text { offices }\end{array}$ & $\begin{array}{l}\text { Price per } \\
\text { office }(£)\end{array}$ & $\begin{array}{c}\text { Total } \\
\text { sales }(f)\end{array}$ & $\begin{array}{l}\text { Judges } \\
1695\end{array}$ & $\begin{array}{l}\% \text { Incr. } \\
\text { from sales }\end{array}$ \\
\hline \multicolumn{3}{|c|}{ May 1691, Mar. 1694, Nov. 1695} & Metz (cont.) & & & \\
\hline $\mathrm{C}(\mathrm{L})$ & 64 & 4 & 28,000 & 112,000 & 74 & 5.71 \\
\hline $\mathrm{C}(\mathrm{C})$ & 6 & & & & 6 & \\
\hline $\mathrm{C}(\mathrm{P})$ & 6 & & & & 0 & \\
\hline PR & 0 & 1 & 25,000 & 25,000 & 1 & N/A \\
\hline $\mathrm{CR}$ & 0 & 10 & 20,000 & 200,000 & 10 & N/A \\
\hline AG & 2 & & & & 2 & \\
\hline PG & 1 & & & & 1 & \\
\hline Totals & 92 & 17 & & 437,000 & 109 & 18.48 \\
\hline \multicolumn{7}{|c|}{ Nov. $1691 \quad$ Pau $^{\mathrm{d}}$} \\
\hline $\mathrm{PP}$ & 1 & & & & 1 & \\
\hline PM & 3 & 1 & 45,000 & 45,000 & 7 & 33.33 \\
\hline $\mathrm{C}$ & 22 & 6 & 30,000 & 180,000 & 46 & 27.27 \\
\hline AG & 2 & & & & 2 & \\
\hline PG & 1 & & & & 1 & \\
\hline Totals & 29 & 7 & & 225,000 & 57 & 24.14 \\
\hline
\end{tabular}

Aug. 1692 Grenoble
PP

PM

PE

$\mathrm{CH}$

$\mathrm{C}(\mathrm{L})$

$\mathrm{C}(\mathrm{C})$

AG

PG

Totals

\section{1}

3

6

1

47

4

2

1

$65 \quad 4$

Jun. 1693 Aix

PP

PM

PE

C(L)

$\mathrm{C}(\mathrm{C})$

C(G)

AG

PG

Totals

Grand totals

4

\begin{tabular}{rrrrrr}
1 & & & & 1 & \\
7 & 2 & 120,000 & 240,000 & 9 & 28.57 \\
3 & & & & 3 & \\
9 & 6 & 50,000 & $300,000 \AA$ & 55 & 12.24 \\
1 & & & & 1 & \\
1 & & & & 1 & \\
2 & 1 & 40,000 & 40,000 & 3 & 50.00 \\
2 & & & & 2 & \\
6 & 9 & & 440,000 & 75 & 13.64 \\
8 & 92 & & $6,792,000$ & 1,128 & 9.12 \\
\hline
\end{tabular}




\section{Table 4 (cont.)}

Abbreviations: PP: First (Premier) President; PM: président à mortier; PE: président des enquêtes; $\mathrm{C}(\mathrm{L})$ : lay councillor; $\mathrm{C}(\mathrm{C})$ : clerical councillor; $\mathrm{C}(\mathrm{O})$ and $\mathrm{C}(\mathrm{NO})$ : originaire and non-originaire councillors in the Parlement of Rennes; $\mathrm{CH}$ : chevalier d'honneur: an office which existed in only a few parlements before 1702, when it became more general - it resembled that of councillor but was reserved for members of the old nobility, a concession to noble complaints against the social implications of venal office; PR: président aux requêtes; CR: conseiller et commissaire aux requêtes; AG: avocat général; PG: procureur général.

Notes:

a The 'Judges 1695' column also reflects the union to the Parlement in 1679 of the Chambre de l'Édit, a chamber previously reserved for Protestants.

b Explanations are necessary for the anomalies in the 'PM', 'PE', and ' $\mathrm{C}(\mathrm{L})$ ' entries in the 'Judges 1695' column. At some point in the 1690s, a ninth président à mortier was created and took his seat; but I have no record of that creation and sale, so I do not associate it with the edict of February 1691. Two sitting councillors purchased the commissions of président des enquêtes created in 1691 and therefore moved from the ' $\mathrm{C}(\mathrm{L})$ ' into the 'PE' category; but the creation of these commissions does not count as the creation of new offices.

c The 'C(P)' entry in 'Judges 1665 ' reflects the number of offices reserved for Protestant councillors; these were subsequently converted to ' $\mathrm{C}(\mathrm{L})$ ' status and so appear in 'Judges 1695'.

d In addition to the office creations of November 1691, the government merged the Chambre des Comptes of Pau with the Parlement, thus requiring larger numbers in the 'Judges 1695' column than office creations per se would entail.

${ }^{\mathrm{e}}$ Includes redemption of offices by Parlement

${ }^{\mathrm{f}}$ (For the reasons given in the entries for Bordeaux, Toulouse, and Pau, the columns entitled 'Judges 1665', 'New offices' and 'Judges 1695' are not intended to total. Sources: Rennes: BN, Actes R., 23,614 (624): edict of October 1689; AN, P 3317 : 'nouvelles créations' chapitre; Bordeaux: AN, P 3318: 'nouvelles créations' chapitre; Bezons, intendant, Bordeaux, to Pontchartrain, 10 February 1691, AN, G7, 135; Paris: BN, Actes R., F. 23,614 (885): edict of November 1690; AN, P 3317 and P 3318: 'nouvelles créations'; Toulouse: AN, G7 1350: edict of February 1691; AN, P 3318 and 3319: 'nouvelles créations'; Rouen: AN, G7 493: edict of March 1691; AN, P 3318 and 3324: 'nouvelles créations'; Faucon de Ris, first president, Rouen, to Pontchartrain, 10 April 1691, AN, G7 493; Dijon: BM, Dijon, MS 769 (Registres du Parlement): 4 April 1691, p. 29: edict of March 1691; AN, P 3318: 'nouvelles créations'; Metz: BN, Actes R., F. 23,614 (989): edict of May 1691; ibid., F. 23,615 (497): edict of March 1694; ibid., F. 23,615 (730): edict of November 1695; AN, P 3318, 3322, 3323, and 3326: 'nouvelles créations'; Pau: BN, Actes R., F. 23,614 (1197): edict of November 1691; AN, P 3319 and 3324: 'nouvelles créations'. This edict also joined the Chambre des Comptes and the Parlement into a single tribunal, increasing the Parlement from 29 to 57 judges; Grenoble: BN, Actes R., F. 21,776 (80): edict of August 1692. The Parlement redeemed a président à mortier for 90,000 livres and a conseiller clerc for 24,000 livres. The prices for the other offices are my estimates; Aix: BN, Actes R., F. 23,615 (310): edict of June 1693. 
Table 5 Conversion to venality and sale of offices, 1692-1693: Parlements of Besançon and Tournai

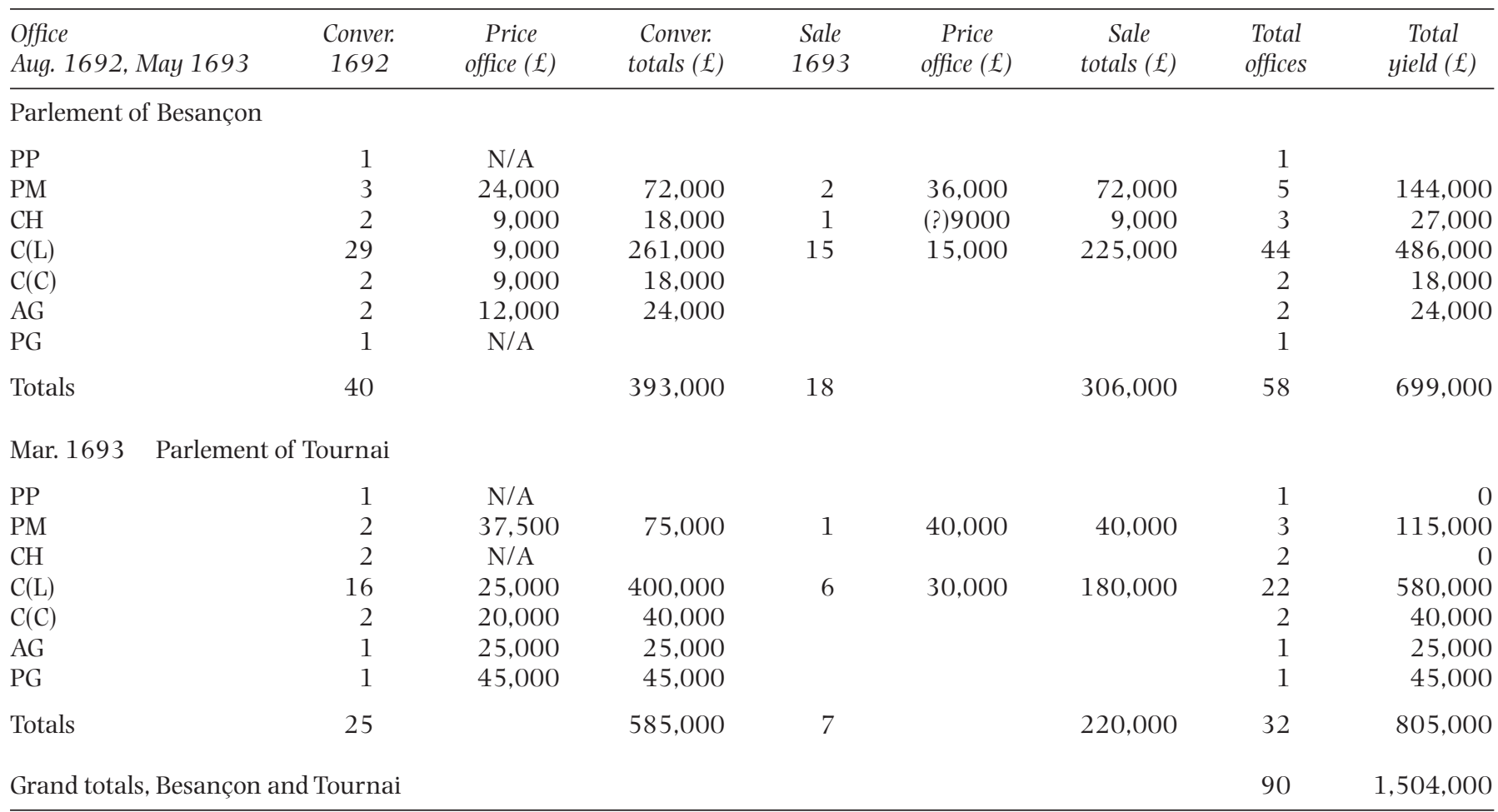

Abbreviations: See Table 4.

Sources: Besançon: BN, Actes R., F. 23,615 (112): edict of August 1692; Boisot, procureur général, to Pontchartrain, 7 May 1693 , AN, G7 277. See also AN, G7, 1342: MS 41, 'Mémoire d'Observations', c. 1704; Gresset, Vénalité des Offices, pp. 43-44. Tournai: BN, Actes R., F. 23,615 (229): edict of March 1693, and Z. Thoissy 11 (ff. 366r-367v), edict of May 1689; AN, P 3321: 'nouvelles créations'.; AN, G7, 360: 'Soumission faite au Roy par les anciens conseillers au Parlement de Tournay', 1693-1694. 
in their venal offices. In gratifying contrast with the past, these administrations proved strong enough to require the judges to pay forced loans, or augmentations de gages, to secure admission to the paulette. Pontchartrain even collected 'voluntary' augmentations de gages, which no other administration had done to any significant degree. Pontchartrain also created and sold new offices in the parlements and, for the first time, did so without incurring opposition, delay or the need to compromise. Putting his sums together, the "voluntary' augmentations de gages of 1689 yielded 3.15 million livres, the regular augmentations de gages of 1692 produced 6.11 million livres, and the sale of offices of 1689-1695 brought in 7.48 million livres, a total of 16.74 millions (Tables 4 and 5). There can be no doubt that this was far more than any government had ever collected from the parlements in any comparable period of time. For the magistrates, this meant rising indebtedness, the mortgaging of their offices and the decline of office values. The government of Louis XIV, so far from respecting the venal interests of the parlements, as revisionist historians have argued, manipulated and exploited those offices to a degree that exceeded the abilities of its predecessors. It would be even more successful in the War of the Spanish Succession; and the financial difficulties of the judges would increase.

\section{Notes}

1 Mousnier, Vénalité, pp. 8-10, 95-116; Howell A. Lloyd, 'The Political Thought of Charles Loyseau (1564-1627)', European Studies Review 11 (January 1981), 53-82; Koenraad Walter Swart, Sale of Offices in the Seventeenth Century (The Hague, 1949).

2 AD, I-V, IBc 1 (Remonstrance of June 1666, Parlement of Rennes); AN, G7, 1342 (Remonstrance of Parlement of Besançon, 21 November 1702); BN, Fonds fr., 16,524: representations of Parlement of Paris, 1704, ff. 69r-71r; Richelieu, Testament Politique, p. 238; BN, Fonds fr., 7,009 ('Mémoire adressée à Louis XIV sur l'état politique ... de France', 1688), f. 19; Ranum, Fronde, pp. 18, 76-77.

3 Lavisse, Le Roi. Colbert, pp. 361-364; Mousnier, Vénalité, p. 85; Moote, Revolt of the Judges, pp. 367, 374; Parker, Making of Absolutism, pp. 140-141, 148; Mettam, Power and Faction, pp. 111, 114-115, 155; Beik, Absolutism and Society, pp. 279-339 (by implication). Hamscher, Parlement of Paris, pp. 62-81, needs no emendation.

4 Glenn Joseph Ames, Colbert, Mercantilism, and the French Quest for Asian Trade (DeKalb, Ill., 1996), pp. 18-26; Cole, Colbert and Mercantilism, I, 478-501; BN, Actes R., F.23,612 (769): declaration of 27 August 1664.

5 BN, Actes R., F. 23,613 (15): declaration of 28 February 1669; Oppède, first president, Aix, to Colbert, 1 June 1669, BN, Mél. Colbert, 153, ff. 53rv-54v; ibid., 151, ff. 81rv-82r (delinquents in the Parlement of Bordeaux); AD, I-V, IBb (Registres secrets, Rennes) 232: 2 and 9 April 1669 and 233: 16 December 1670; Mousnier, Vénalité, pp. 286, 658.

6 BN, Actes R., F.23,613 (630): declaration of 27 October 1674. 
7 Colbert to intendants, 18 December 1674, Lettres, II, pt. i, 368, and to d'Argouges, first president, Rennes, 28 December 1674, ibid., p. 369.

8 BM, Aix, MS 955 (Délibérations du Parlement): 9 January 1675, ff. 112rv; BM, Dijon, MS 768 (Registres du Parlement): 10 January 1675, pp. 325-326; AD, Moselle, B 278 (Registres secrets, Metz): 17 January 1675, f. 82rv; AD, I-V, IBb 243 (Registres secrets, Rennes): 8 January 1675, f. 87rv; BM, Rouen, MS Y214/26 (Registres secrets): 18 January 1675, p. 274, and BN, Fonds fr., 22,455 (Histoire du Parlement de Rouen), p. 359. The declaration is in BN, Actes R., F. 23,613 (636); AN, P 3352 (Quittances des augmentations de gages ... 1675): payments from the provincial parlements. For the Parlement of Paris, see AN, E 480/B: decree of 31 December 1674, no. 23, and E 485/B-486/A: decree of 31 May 1675, no. 33, and BN, Mél. Colbert, 249, 'Estat des augmentations de gages. 1676', ff. 33lr-397r. Colbert expressed his satisfaction with Rouen's augmentations de gages in his letter to Le Blanc, intendant, Rouen, 30 November 1675, BN, Fonds fr., 8,751, f. 7rv.

9 Quoted in John Lough, ed., France Observed in the Seventeenth Century by British Travellers (Boston, 1985), p. 88.

10 Mousnier, Vénalité, pp. 284, 293, 300. (In 1638, the government increased its appraisals of office values by one-third, the first such change since the inception of the paulette in 1604.)

11 BN, Actes R., F. 23,614, nos 134 and 138: edict and declaration of October 1683; F. 23,615, nos 143 and 151: edict and declaration of September 1692; F. 23,616, nos 845 and 853: edict and declaration of August 1701.

12 Mémoire présenté au Roy par M. le Pelletier . . . pour luy rendre compte de son administration', BN, Fonds fr., 7750; AN, X1A 8402 (Conseil secret): 24 November 1683, f. 464v; BM, Aix, MS 955 (Délibérations du Parlement): 1 December 1683, ff. 288v-289r; BM, Dijon, MS 768 (Registres du Parlement): 1 December 1683, pp. 566-567; AD, Moselle, B 296* (Registres secrets, Metz), 28 December 1683, f. 47r, and 3 January 1684, ff. 50v-51v. For the compliance of the Parlements of Bordeaux, Grenoble and Rouen, see AN, P 3359 (Registre . . . des quittances d'augmentations de gages . . . 1683, 1684); and, for Pau, see P 3365. See also Brûlart, first president, Dijon, to Le Peletier, controller general, 20 December 1683, BM, Dijon, MS 542, ff. 198rv; Smedley-Weill, Intendants de Louis XIV, pp. 230-231.

13 Pontchartrain, controller general, to Harlay, first president, Paris, 30 August 1692, BN, Fonds fr., 17,424, f. 29r; Chamillart, controller general, to Harlay, 26 April 1701, ibid., 17,436.

14 Rachapt de l'annuel', memorandum, 1708, in AN, G7, 1325; AN, E 613: decree of 10 February 1693, no. 40 (the Enquêtes chamber); Moote, Revolt of the Judges, p. 44 and ff., treated the 'jeopardy' of venal office under Louis XIII.

15 Le Peletier, controller general, to intendants, 5 August 1689, AN, G7, 5; , Actes R., F. 23,614 (585): edict of July 1689 for augmentations de gages.

16 Estat général des offices sujets au Rachat du prest et annuel', c. 1709, and 'Rachapt de l'annuel', 1708, in AN, G7, 1325; 'Mémoire touchant ce qui se peut faire pour les offices des compagnies supérieures ...', c. 1700, BN, Fonds fr., 16,524 (Harlay), f. 228r; and 'Estat des augmentations de gages', BN, Fonds fr., 7,727, ff. 5r-6v. For the forced loans of other corporate groups, see E. Laurain, Essai sur les présidiaux (Paris, 1896), pp. 64-66; David D. Bien, 'The secrétaires du roi: Absolutism, Corps 
and Privilege under the Ancien Régime', in Vom Ancien Régime zur Franzöischen Revolution, ed. Ernst Hinrichs (Göttingen, 1978), pp. 161-163.

17 John J. Hurt, 'The Parlement of Brittany in the Reign of Louis XIV' (Ph.D. diss., University of North Carolina, 1969), 198-240; Jean-Claude Paulhet, 'Les parlementaires toulousains à la fin du XVIIe siècle', Annales du Midi 76 (April 1964), 199-200; Maurice Virieux, 'Une enquête sur le Parlement de Toulouse en 1718', Annales du Midi 87 (1975), 47-49; Beik, Absolutism and Society, pp. 53, 79; Kettering, Parlement of Aix, pp. 231-232; Dewald, Formation of a Provincial Nobility, pp. 114-116, 125; F. Momplot, 'Recherches sociales sur les conseillers au Parlement de Paris, 1685 à 1690', (mémoire maîtrise, histoire, Paris IV, 1970); François Bluche, Les magistrats du Parlement de Paris au XVIII siècle (Paris, 1960), pp. 151-152, nn. 117, 128, 129, 131; Jean-Pierre Labatut, Les ducs et pairs de France au XVIIe siècle. Étude sociale (Paris, 1972), p. 324.

18 John J. Hurt, 'Les offices au Parlement de Bretagne: aspects financiers', Revue d'histoire moderne et contemporaine 23 (January-March 1976), 12, 23-24; Daniel Zolla, 'Les variations du revenu et du prix des terres en France au XVIIe et XVIIIe siècles', Annales de l'école libre des sciences politiques 8 (1893), 299-326, 439-461, 686-705; 9 (1894), 194-216, 417-432; Pierre Goubert, Beauvais et le Beauvaisis de 1600 à 1730 (2 vols; Paris, 1960), I, 377-395, 411-419, 459-461, 493-512, 520-532; Emmanuel Le Roy Ladurie, Les paysans de Languedoc (2 vols; Paris, 1966), I, 511-533, 585-595, 637-638; Jean-Marc Moriceau, Les fermiers de l'île-de-France (Paris, 1994), pp. 515-529, 549-555.

19 Jean-Paul Poisson, 'De quelques nouvelles utilisations des sources notariales en histoire économique (XVIIe-XXe siècle)', Revue Historique 249 (January-March 1973), 16-17. It is rightly argued that the financial services of the notaries reduced the need in France for a central bank modeled after that of England.

20 BM, Aix, MS 955 (Délibérations du Parlement): 1 December 1683, ff. 288v-289r; MS 977 (Délibérations), 31 March 1702, ff. 130v-132rv; BM, Dijon, MS 768 (Registres du Parlement): 1 December 1683, pp. 566-567, and 8 January 1684, p. 569; MS 769 (Registres), 22 September and 20 December 1692, pp. 64-65 and 76; AN, P 3379 (Augmentations de gages . . . 1692); BN, Fonds fr., 16,524: notes, c. 1703 , f. 214 r, show the borrowing en corps of the Grand-Chambre of the Parlement of Paris.

21 La Tresne, first president, Bordeaux, to Chamillart, controller general, 17 September 1701, AN, G7, 139; AD, Isère, 2B4* (Livre rouge, Grenoble), f. 272rv; AD, Moselle, B 308 (Registres secrets, Metz), 13 September 1689, ff. 20r-21v; Picquet, greffier en chef, Rennes, to magistrates, 3 October 1692, AD, I-V (Rennes), B (Parlement) Registre littéraire, f. 22; BN, Fonds fr., 22,455 (Rouen), 5 December 1692, p. 442; Morant, first president, Toulouse, to Pontchartrain, controller general, 24 September 1692, AN, G7, 301. The registers in AN, P 3359, 3361, 3381, 3386 and 3393 provide the names of the creditors of the judges, typically merchants, barristers, widows and 'bourgeois of Paris' (an elastic term), a social identity similar to that detected in Claude Michaud, 'Notariat et sociologie de la rente à Paris au XVIIe siècle', Annales. E.S.C. 32 (1977), 1154-1187.

22 BN, Actes R., F. 23,614 (134): October 1683; F. 23,615 (143): September 1692; F. 23,616 (845): August 1701; Loyseau, Cinq Livres, Bk III, chs. vi, viii.

23 BN, Actes R., F. 23,614 (87): edict of February 1683. 
24 Pontchartrain, chancellor, to du Vigier, procureur général, Bordeaux, 4 August 1709, BN, Manuscrits fr., 21,130; AD, Gironde, 1B 30 (Registre d'enregistrement), 1693-1710: examples of office seizures; Hurt, 'Parlement of Brittany in the Reign of Louis XIV', pp. 225-230.

25 See Colbert's circular letter to intendants in BN, Clairambault, 462, 14 July 1679; Hamscher, Parlement of Paris, pp. 65-66; Colbert, 'Mémoire pour l'instruction du Dauphin', Lettres, II, pt. i, 'Introduction', p. ccxv.

26 Controller General Chamillart to First President Harlay of Paris, 2 November and 3 and 6 December 1699: BN, Fonds fr., 17,436; Chamillart's correspondence with the provincial first presidents is in AN, G7, 1769-1773.

27 David Bien, 'Offices, Corps, and a System of State Credit: The Uses of Privilege under the Ancien Régime', in The Political Culture of the Old Regime, ed. Keith M. Baker (Oxford, 1987).

28 Mousnier, Vénalité, pp. 360-362; Dewald, Formation of a Provincial Nobility, pp. 138-140; Kettering, Judicial Politics, pp. 221-224; André Germond, 'Les parlementaires Bretons de 1661 à 1720', (Diplôme d'Études Supérieures, Faculté des Lettres, Université de Haute-Bretagne, c. 1964, Rennes 2); La Roche-Flavin, Treize livres, Bk II, ch. xxii. The reform edict of December 1665 acknowledged that offices represented 'la meilleure partie' of office-holders' wealth.

29 William Doyle, Venality. The Sale of Offices in Eighteenth-Century France (Oxford, 1996), pp. 8-10; Salmon, Society in Crisis, pp. 152-154, 220-222; Davis Bitton, 'History and Politics: The Controversy over the Sale of Offices in Early Seventeenth Century France', in Action and Conviction in Early Modern Europe. Essays in Honor of E.H. Harbison, ed. Theodore K. Rabb and Jerrold E. Seigel (Princeton, NJ, 1969), pp. 390-403; Mousnier, Vénalité, pp. 35-36, 87-89, 645-662; Loyseau, Cinq Livres, Bk III, ch. i.

30 États et évaluation', 1665; BN, Actes R., F. 23,612 (842): edict of December 1665 (also in Isambert, Recueil général, XVIII, 67-69); Hamscher, Parlement of Paris, pp. 157-164.

31 États et évaluation', 1665, lists estimated office prices. For true market prices in Rennes and Aix in the 1660s, see Germond, 'Parlementaires bretons', and Kettering, Judicial Politics, p. 224. For examples of fixation prices, see the edict of 1665 (Parlement of Paris); AD, I-V (Rennes), 1Ba 22, ff. 395-396: edict of December 1665; AM, Bordeaux, MS 795 (Registre secret): 16 January 1666, pp. 198-199; Eugène Lapierre, Le Parlement de Toulouse (Paris, 1875), p. 35. For the hostility of the Parlement of Paris to the reform edict, see ch. 1, this volume, pp. 21-22; for provincial opposition, see Hurt, 'Parlement of Brittany in the Reign of Louis XIV’, pp. 122-124; BM, Aix, MS 975 (Délibérations du Parlement): 5 January 1666, f. 377r; AM, Bordeaux, MS 795 (Registre secret): 16-19 January 1666, ff. 196-201; AD, S-M (Rouen), IB 195 (Registres secrets): 7 January 1661, ff. 49v-50r; avocats généraux, Parlement of Rouen, to Colbert, 4 January 1666, BN, Mél. Colbert, 136, f. $7 \mathrm{v}$.

32 Hamscher, Parlement, pp. 21-22; AD, I-V (Rennes), 2Eb (La Bourdonnaye) 25: Berthou de Kerverzio papers.

33 Mettam, Power and Faction, p. 260, incorrectly wrote that the fixation ceilings 'ipso facto lowered the amount which had to be paid for the annuel, the yearly payment under the terms of the paulette, because this was calculated on the basis of 
one-sixtieth of the official value'. In fact, the fixation did not affect in any way the appraised value of offices upon which magistrates paid their paulette. See Mousnier, Vénalité, p. 161, and 'Mémoire sur l'évaluation des offices sujets aux Revenus Casuels', c. 1715, AN, G7, 1325. For the venal office legislation, see BN, Actes R., F. 23,613 (21): edict of March 1669 and (237): declaration of November 1671.

34 Ormesson, Journal, II, 614-616, 627; AN, E 461/B-462/A: decree of 4 April 1673 in favour of the heirs of président à mortier de Brie. For enforcement of the deposit requirement, see BN, Fonds fr., 7659 (Bienfaits du Roi, 1686), f. 5r, and Le Peletier, controller general, to Sève, first president, Metz, 25 June 1687, Arthur-Michel de Boislisle, ed., Correspondance des contrôleurs généraux des finances avec les intendants des provinces (3 vols; Paris, 1874-1897), I, 109.

35 Hurt, 'Les offices au Parlement de Bretagne', pp. 22-24, treats capital appreciation.

36 Clamageran, Impôt, II, 663-669; Doyle, Venality, pp. 23-24; Forbonnais, Recherches et considérations, III, 96-100; AN, P 3298: 'nouvelles créations'. Moote, Revolt of the Judges, p. 374, and Roland Mousnier, 'Conclusion', Dix-septième siècle 122 (1979), 77 , suggested that Louis XIV never created offices in the parlements.

37 Doyle, Venality, pp. 26-37; Bonney, King's Debts, pp. 300, 317.

38 BN, Actes R., 23,614 (624): edict of October 1689; AN, P 3317: 'nouvelles créations' chapitre (new offices in Rennes); Pontchartrain, controller general, to Bezons, intendant, Bordeaux, 31 October 1689, Boislisle, Correspondance, I, 200.

39 AN, P 3318: 'nouvelles créations', (edict of September 1690); Bezons, intendant, Bordeaux, to Pontchartrain, 10 February 1691, AN, G7, 135.

40 The increase of 9.12 percent is based on a corps of 1,008 parlementary judges in 1665, as established by Colbert's inventory. It is not clear whether the traitants also collected the remise en dehors, the surcharge of 10 percent (two sols per livre).

41 Louis XIV created the Parlement of Besançon in 1674-1676 and gave it jurisdiction over the newly conquered province of Franche-Comté: A. Estignard, Le Parlement de Franche-Comté de son installation à Besançon à sa suppression (2 vols; Paris, 1892), I, 30-100. The conseil souverain of Tournai became a parlement in 1686 with jurisdiction over Flanders: BN, Fonds fr. 16,873: 'Questions . . qui regardent le Conseil Souverain de Tournay', ff. 299rv-301r. When the Treaty of Utrecht (1713) awarded the city of Tournai to the Austrian Habsburgs, Louis XIV moved the Parlement to Douai.

42 AN, X1A 8407 (Conseil secret): 23 November 1690; BM, Dijon, MS 769 (Registres du Parlement): 4 April 1691, p. 29; BM, Aix, MS 955 (Délibérations du Parlement): 19 June 1693, f. 424v; Morant, first president, Toulouse, to Pontchartrain, 7 March 1691, AN, G7, 300; (Brûlart gave a similar report for the Parlement of Dijon: letter to Pontchartrain, 5 April 1691, AN, G7, 157); for the Parlement of Grenoble, see BN, Actes R., F. 21,776 (80).

43 BM, Dijon, MS 769 (Registres du Parlement): 4 April, 13 June and 18 July 1691; 13 February, 12 March and 25 March 1692; Metz: AN, P 3318, 3322, 3323, and 3326; BM, Aix, MS 976 (Délibérations du Parlement): 8 October 1693, f. 431r; Le Bret, first president, Grenoble, to Pontchartrain, 14 April 1693, AN, G7, 462; AD, I-V, IBb (Registres secrets, Rennes) 274: 13 May and 22 May 1690 and AN, P 3317; Maurice Gresset, L'introduction de la vénalité des offices en Franche-Comté (Besançon, 1989), pp. 57-61, 74, 113, 118; AN, G7, 260: 'Sousmission faite au Roy par les anciens Conseillers du Parlement de Tournay ...'; AN, P 3321: 'nouvelles créations' 
chapitre. The government screened candidates for président à mortier and procureur général for political reliability, but the other offices were not considered important enough for political scrutiny: Pontchartrain to Harlay, first president, Paris, 30 October 1690, BN, Fonds fr., 16,524, f. 10v.

44 Morant, first president, Toulouse, to Pontchartrain, controller general, 26 March 1692, AN, G7, 300; Bâville, intendant, Toulouse, to Pontchartrain, 21 May 1692, ibid.; AN P 3318: 'nouvelles créations': 24 August 1691 and 5 January 1692, Parlement of Toulouse; Bezons, intendant, Bordeaux, to Pontchartrain, 24 November 1691, AN, G7, 724; Aulède, first president, Bordeaux, to Pontchartrain, 24 November 1691, Boislisle, Correspondance, I, 267; AN, P 3318: 'nouvelles créations': entries of 9 March, 6 April and 12 May 1691, Parlement of Bordeaux; Larcher, intendant, Rouen, to Pontchartrain, 5 September 1691, AN, G7, 493; Montholon, first president, Rouen, to Pontchartrain, 18 June 1692, G7, 494; Le Camus, lieutenant civil, Rouen, to Pontchartrain, 28 September 1694, AN, G7, 494; AN, P 3318: 'nouvelles créations': 26 and 30 June 1691; P 3324: 'nouvelles créations': 26 July 1697, Rouen.

45 Cambon, aspiring councillor in the Parlement of Toulouse, to Pontchartrain, 5 November 1693, AN, G7, 30; Bezons, intendant, Bordeaux, to Pontchartrain, 3 July 1691, AN, G7, 135; Larcher, intendant, Rouen, to Pontchartrain, 5 September 1691, AN, G7, 493.

46 Chamillart, controller general, to Harlay, first president, Paris, 28 November 1702 , BN, Fonds fr., 16,524.

47 BN, Actes R., F. 23,614 (885): edict of November 1690; Harlay, 'Mémoire touchant ce qui se peut faire pour les officiers des compagnies supérieures', c. 1700, BN, Fonds fr., 16,524, f. 229r; Bluche, Magistrats du Parlement de Paris, pp. 82-83.

48 Brûlart, first president, Dijon, to Pontchartrain, 15 February 1691, BM, Dijon, MS 542, ff. 326v-328r; 'Mémoire sur la proposition des nouvelles créations', ibid., ff. 328r-329r, AN, G7, 157; Faucon de Ris, first president, Rouen, to Pontchartrain, 24 and 31 March 1691, AN, G7, 493.

49 The royal council transferred lawsuits from one parlement to another to preclude conflicts of interest between litigants and judges; but the latter still found such transfers, called evocations, offensive: Hamscher, Conseil privé, pp. 69-79.

50 BN, Actes R., F. 23,614 (624): edict of October 1689 (Rennes) and ibid. (885): edict of November 1690 (Paris). For Bordeaux, see Bezons, intendant, to Pontchartrain, controller general, 10 February 1691, AN, G7, 135. See also Pontchartrain to Harlay, first president, Paris, 30 October 1690, Paris, BN, Fonds fr., 16,524 (Harlay), ff. 10r-11r., and 'Mémoire sur la proposition des nouvelles créations' (Parlement of Dijon), AN, G7, 57.

51 Le Bret, first president, Grenoble, to Pontchartrain, 14 April 1693; BM, Aix, MS 976 (Délibérations du Parlement): 24 July 1693, ff. 426v-427v; undated letter from Pontchartrain, ff. 432v-433r; MS 977: 14 June 1695, ff. 5-6; Balthasar de Clapiers-Collonques, Chronologie des officers des Cours souveraines de Provence (Aixen-Provence, 1909), pp. 24-25, 65-66, 117-118. 